\title{
THE EFFECTIVENESS OF SIMULATION AND ROLE PLAY TECHNIQUE TO TEACH SPEAKING FOR HIGH AND LOW MOTIVATION STUDENTS
}

\author{
Maria Agustin Daniastuti \\ A Post Graduated Student of Universitas Negeri Semarang
}

\begin{abstract}
This study's purpose is to find out the significance of motivation and teaching learning technique effect toward students learning result score on speaking skill. this research was conducted in Tarciusius Vocational School Semarang and took thirty one students as data source. Experimental research was chosen to solve the research question with the help of the SPSS statistical program to increase the accuracy. This research wes employed questionnaire, $t$-test, and f-test in data collection. Based on the finding, speaking skill learning result by using simulation technique and role play tend to achieve better result on post-test than pre-test. Future testing shows that speaking skill learning result by using simulation technique much better than role play. Other findings show that high motivation studentssignificantly influence toward speaking learning result by using simulation technique and role play. In other hand Low motivation students does not significantly influence toward speaking skill learning result. Finally, this research conclude that simulation technique is appropriate learning technique to improve speaking learning result than role play.
\end{abstract}

Keyword: Motivation, Simulation Technique, Role play

\section{Introduction}

Language cannot be separated from human activities. People share their thoughts, feelings, experiences, and many things with others by using language. Language becomes the main instrument of communication because people use language to conduct communication in their every social interaction. English is one of languages that becomes international language. It means that English is used by many people around the world to communicate or deliver something, includes in teaching and learning process. In Indonesia, English also becomes one of important subjects in national examination for high school level, beside mathematics and Indonesian language subject. Therefore, mastering English is very important.

In order to master English or any language as second, or even, as foreign language, there must be some massive problem especially on speaking skill. first, unlike reading or writing, speaking skill happens in real time; usally the person you are talking to is waiting for you to respond the conversation. This problem caused the conversation become awkward or died immediately. Second, when you speak, there is no time to edit and revise what you wish to say like in writing.

These reasons make the speaking skill is very essential skill. not only for our daily life, the kind of skill help us to gather some important information from other people. Lacking these aspect will bring some problem in our future social life. In line with the reason before, Aungwatanakun in Oorade $(2012 ; 511)$ state that ability to speak is most essential skill since it is the basic for communication, include English.

According to Harmer in Solcova (2011) states that role play and simulation increase learners' self confidence and encourage more hesitant learners to speak because it is not themselves who they present when conversation happens and thus they do no have to take the responsibility for their utterance and actions. Therefor, from the statement of Harmer above stimulate the researcher to conduct similar study. This research combining the simulation technique and role play as teaching technique in English speaking skill to motivate the students that have different motivation.

The objective of the research were as follows : (1) to explain how simulation technique is more effective teaching technique on learning speaking skill; (2) to explain motivated students, high and low motivation students, significantly influence toward speaking skill learning result by using simulation technique; (3) to explain motivated students, high and 
low motivation students, significantly influence toward speaking skill learning result by using role play.

\section{Literature Review}

Concept of Speaking

Speaking is "the process of building and sharing meaning through the use of verbal and non-verbal symbols, in a variety of contexts" (Chaney, 1998, cited in Shrouf, 2012). Speaking is an interactive process of constructing meaning that involves producing and receiving and processing information (Brown, 1994).

Based on Richard (2008), mastery of speaking skills in English is a priority for many secondlanguage or foreign-language learners. Consequently, learners often evaluate their success in language learning as well as the effectiveness of their English course on the basis of how much they feel they have improved in their spoken language proficiency.

\section{Purposes of Speaking}

The purposes of teaching speaking are (1). to produce the English speech sounds and sound patterns, (2). To select appropriate words and sentences according to the proper social setting, audience, situation and subject matter, (3). To use word and sentence stress, intonation patterns and the rhythm of the second language, (4). To organize their thought in a meaningful and logical sequence, and (5). To use the language as means of expressing values and judgements.

Based on Richard (2008) there are numerous attempts have been made to classify the functions of speaking in human interaction. In his research he expanded three-part version of Brown and Yule's framework (after Jones, 1996, and Burns, 1998) about function of speaking: talk as interaction; talk as transaction; talk as performance. Each of these speech activities is quite distinct in terms of form and function and requires different teaching approaches.

\section{Motivation}

Gardner (Ellis,1994:509) stated that motivation refers to the directed effort individual learners make to learn the language.In Ellis (1994:515), the notion of intrinsic motivation is an old one in psychology. It was developed as an alternative to goal-directed theories of motivation that emphasize the role of extrinsic reward and punishment. Keller (cited in Ellis, 1994) said interest as one of the main elements of motivation. It as positive response to stimuli based on existing cognitive structure. Fauziati (2011:192-193) stated that second language learners can be intrinsically or extrinsically motivated to succeed in their task

Several research state in Saputra study (2017) state that there is important relationship between motivation and learning. Pepe, Bell, and Yetkin stated that motivation maintain students for longer study time so it can make the best result. Yet, it very depend how study environment support their motivation of study. Teacher role is very crucial to stimulate motivation because students mostly learn on classroom. a good guidance will help them understand correctly and efficiently which eliminated bad emotion such as anxious or desperation.

\section{Simulation}

Similar with role play, Brown (2007) elaborate that simulation are more elaborate then role plays. In simulation, props and documents provide a somewhat realistic environment for language practice. Solcova (2011) in her study, state that simulation is a kind of role play with the only difference that learner use realia, that is real object to support teaching learning process.

Silvia in a study state that there are similarity of simulation with role play. It possible that both of the technique provide a practical and real situation as their benefit in supporting teaching learning. Either of them also bring some particular situation and encourage students to learn based on "become another prople" situation for better undrestanding. Although, Kenner in Silvie argue that simulation give a chance students to apply more theory, develop critical skill, and provide a welcome relief from the everyday task of reading and preparing for classes.

\section{Role Play}

Role play is a technique that allows students to explore realistic situation by interacting with other people in a managed way in order to develop experience. According to Ladousse 
in Kusnierek (2015) Role play can be defined as one of whole gamut of communicative techniques which develops fluency in language students, which promotesinteraction in the classroom and which increase motivation. Not only peer learning encourage by it, but also sharing between teacher and students of the responsibility for the learning process.

Moreover, Role play can be very useful dress rehearsal for real life, especially for people who are learning English for professional purpose. It fits the desire for realism, since it gives the students the chance to rehearse the typical activities. Another function that very important of the usage of this technique is it can be as facilitatot for linguistic item memorization. Role play provide physical and visual reinforcement that increase involvement and helps to fix vocabulary, structures and grammar (Kusnierek; 2015)

\section{Criteria of Speaking}

In order to explain how students achieve better speaking skill, this research was taking score by using five criteria. First criteria is Vocabulary and as Manser in Susilowati (2012) define vocabulary as total number of word in a language or list of word with their meaning. This criteria has a massive reflection toward people speaking skill in order to express their idea. Lacking of vocabulary cause a gap in every conversation.

Second criteria is pronunciation. Rui Ma (2015) in her study explain that pronunciation is related refential meaning by stress and intonation of target language. People who has good speaking skill produce a proper utterance and can be comprehend by listener in every word.

Effort is the third criteria to measure a good speaking skill. Pace in Utami (2012) that "quality of student effort is defined as how much voluntary behavior or personal investment a student makes for their education. It has been examined as how often students carry out learning activities, such as taking detailed notes during class". giving proper appreciation on students' effort is very important to bring encouragement in learning proccess.
Fluency as the next criteria, commonly define by Fillmore in Richard (1990) as an ability to talk in coherent and fill time with talk. In other definition, this word can be define as "flow" in latin origin. People with a good speaking skill tend to more fluent, accurate, smooth, lucid, and efficient when they engage conversation.

The last criteria is Creativity as Jarger in Wolf (2012) explain as the abilities that are most characteristic of creative people. In line with Jarger, Gerlovina (2011) explain can be define as ability to produce something appropriate, generative, and influential. It may not directly measure people speaking skill, but in context of role play and simulation technique. Creativity appreciation provide students encouragement

\section{Research Design}

This research use experimetal research deesign as a core. This kind of research has unique way to directly attempts to influence a particular variable and can really test hypothesis about cause-and-effect relationship. In eperimental research design, there will be two group of sample that represent data. They are experimental group and control group. In the end of the post test of both group will be compared.

The subject of the research are the eleventh grade students of tarcisius vocational high school semarang. Sample choose by using random sampling which every participant have same and queal chance of being assigned. Researcher choose two different classes with thirty five students in every class. As the variable of this research is motivation as independent variable and teaching technique as dependent variable.

This research conducted quantitative data anaylsis and statistical model. Analysis of Variance or ANOVA analyze the different between two group and thei associated procedures such as "variation" among and 
between groups. t-test and z-test conducted to support ANOVA

\section{Finding \\ Comparative Mean Testing Simulation Technique and Role Play}

According to calculation by using SPSS, researcher obtain mean data and standard deviation simulation technique and role play, as follow :
Based on the result of proccessing data above, can be conducted testing steps to show the significance difference between simulation technique and role play. Does speaking learning result by using both of them obtain significantly different result? Or does simulation technique obtain better result than role play?

Table 4.1 Comparative Mean Testing Simulation Technique and Role Play

\begin{tabular}{|r|r|r|r|r|}
\hline Technique & Mean & \multicolumn{1}{|c|}{$\mathrm{N}$} & $\begin{array}{c}\text { Std. Devia- } \\
\text { tion }\end{array}$ & $\begin{array}{c}\text { Std. Error } \\
\text { Mean }\end{array}$ \\
\hline Simulation & 85.32 & 31 & 5,618 & 1.009 \\
\hline Role Play & 67.10 & 31 & 4,962 & .891 \\
\hline
\end{tabular}

Source : Procceced primary data

Testing steps :

1. Determine $\mathrm{H}_{0}$ which states speaking skill learning score evaluation by using simulation technique obtain same result with role play

Determine $\mathrm{H}_{\mathrm{a}}$ which states speaking skill learning score evaluation by using simulation obtain significantly better result than role play

2. Determine Z-table with alpha $(\alpha)=5 \%=$ 0.05 . Z-table obtained $Z=1.64$.

3. Determine

$$
Z_{\text {Count }}=\frac{\overline{X 1}+\overline{X 2}}{\sqrt{\frac{s_{1}^{2}}{n_{1}}+\frac{s_{2}^{2}}{n_{2}}}}=\frac{82.32-67.10}{\sqrt{\frac{(5,618)^{2}}{31}+\frac{(4,962)^{2}}{31}}}=8.3
$$

4. The result of testing above shows that Zcount is bigger than Z-table $(8.3>1.64)$. it means that $\mathrm{H}_{0}$ is rejected and $\mathrm{H}_{\mathrm{a}}$ is accepted. Thus, speaking skill learning result evaluation by using simulation technique significantly obtain better result then role play

Significance Learning Result of Motivated students by using Simulation

High motivation toward simulation technique According to the result of SPSS proccesing data, it is identified from the regresion equation and hypotesis testing of the influence of students with high motivation toward learning result by using simulation technique and can be seen on the table 2 below:

Table 4.2 High Motivation Towards Simulation technique Coefficient.

\begin{tabular}{|c|c|c|c|c|c|c|}
\hline \multirow{2}{*}{\multicolumn{2}{|c|}{ Model }} & \multicolumn{2}{|c|}{$\begin{array}{l}\text { Unstandardized } \\
\text { Coefficients }\end{array}$} & \multirow{2}{*}{\begin{tabular}{|l} 
Standardized \\
Coefficients \\
Beta \\
\end{tabular}} & \multirow[b]{2}{*}{$t$} & \multirow[b]{2}{*}{ Sig. } \\
\hline & & $B$ & Std. Error & & & \\
\hline \multirow[t]{2}{*}{1} & (Constant) & 62,146 & 8,999 & & 6,906 & 000 \\
\hline & High Motivation &, 591 & 206 &, 559 & 2,861 & 010 \\
\hline
\end{tabular}


Dependent variable (y) : Simulation technique Independent Variable (x) : High Motivation

Data result shows regresion equation $\mathrm{Y}=62.146+0.591 \times$ this can be interpreted as follow :

1. Constante number 62.146 show if motivation $(X)=0$, that is students did not have motivation, then student will obtain learning result taught by using simulation technique 62.146

2. Regression coefficient 0.591 means that if motivation goes up one unit then the value of learning result wil increase 0.591 as well

High motivation impact toward simulation technique can be proceed by hypothesis testing with t-test as follows :

1. Determine $\mathrm{H}_{0}$ which state high motivation students do not obtain significance learning result score by using simulation technique

Determine $\mathrm{H}_{\mathrm{a}}$ which state high motivation students obtain significance learning result score by using simulation technique

2 Detemine t-table value with alpha (a) $5 \%$ or 0.05 and degree of freedom (df) $n-2=20-$ $2=18$. T-table value obtained 1.734 with one right side testing

3 Determine t-count value which can be found on table above as 2.861

4 Testing conclution shows that $\mathrm{t}$-count value more than $\mathrm{t}$-table value $(2.861>1.734)$ means that $\mathrm{t}$-count located in rejection area. then $\mathrm{H}_{0}$ is rejected and $\mathrm{Ha}$ is accepted. Significance number 0.010 less than alpha (a) 0.05 shows Ha significance is accepted. Thus high motivation students obtain significance learning result score by using simulation technique

\section{Significance Learning Result of Motivated students by using Role play}

High Motivation Toward Role Play

According to the result of SPSS preccesing data, be able to obtain regresion equation and hypotesis testing of the influence of students with high motivations toward learning result by using role play and can be seen on the table below
Table 4.4 High Motivation Towards Role Play Coefficient.

\begin{tabular}{|l|l|l|l|l|}
\hline \multicolumn{2}{|l|}{$\begin{array}{l}\text { Unstandardized } \\
\text { Coefficients }\end{array}$} & $\begin{array}{l}\text { Standardized } \\
\text { Coefficients }\end{array}$ & \multirow{3}{*}{ Sig. } \\
\cline { 1 - 4 }$B$ & Std. Error & Beta & & \\
\hline 50,571 & 7,670 & & 6,593 &, 000 \\
\hline 461 & 190 & 477 & 2,428 & 025 \\
\hline
\end{tabular}

Source : processed primary data Dependent variable (y) : Role play Independent Variable (x) : High motivation

Data result shows regresion equation $\mathrm{Y}=50.571+0.461 \times$ this can be interpreted as follow :

1. Constante number 50.571 show if motivation $(X)=0$, then students with high motivation will obtain learning result taught by using role play 50.571

2. Regression coefficient 0.461 means that if motivation goes up one unit then the value of learning result wil increase 0.461 as well

High motivation impact toward role play can be proceed by hypothesis testing with t-test as follows:

1. Determine $\mathrm{H}_{0}$ which state high motivation students do not obtain significance score by using role play Determine $\mathrm{H}_{\mathrm{a}}$ which state high motivation students still obtain significance learning result by using role play

2. Detemine t-table value with alpha (a) $5 \%$ or 0.05 and degree of freedom (df) $n-2=22-$ $2=20$. T-table value obtained 1.725

3. Determine t-count value which can be found on table above as 2.428

4. Testing conclution shows that $\mathrm{t}$-count value more than $\mathrm{t}$-table value $(2.428>1.725)$ means that t-count located in rejection area. then $\mathrm{H}_{0}$ is rejected and $\mathrm{Ha}$ is accepted.testing can also be proceed by comparing significance value and alpha $(\mathrm{a})$ value. Significance number 0.025 less than alpha (a) 0.05 shows Ha significance is accepted. Thus high motivation students still obtain significance learning result even by using role play. 
Low Motivation Toward Role Play

According to the result of SPSS preccesing data, be able to obtain regresion equation and hypotesis testing of the influence of students with low motivations toward learning result by using role play and can be seen on the table below:

Table 4.5 Low Motivation Towards Role Play Coefficient. motivation students do not obtain significance learning result by using role play.

\section{Discussion}

This study mainly focusing on how motivation will bring significance result toward speaking achivement in order to achieve a best result. Speaking skill as main

\begin{tabular}{|l|l|l|l|l|l|l|}
\hline Model & \multicolumn{2}{|l|}{$\begin{array}{l}\text { Unstandardize } \\
\text { d Coefficients }\end{array}$} & $\begin{array}{l}\text { Standardized } \\
\text { Coefficients }\end{array}$ & \multirow{2}{*}{$\mathrm{s}$} & Sig. \\
\cline { 2 - 7 } & & & $\begin{array}{l}\text { Std. } \\
\text { Error }\end{array}$ & Beta & & \\
\hline \multirow{2}{*}{1} & (Constant) & 39,444 & 17,239 & & 2,288 & 056 \\
\cline { 2 - 7 } & Low & & 1,323 & 227 \\
\hline
\end{tabular}

topic was choosen to solve a big trouble of mastering English as foreign language. Harmer (2007) and Oorade (2012) cited their concern toward this issue on their study. Both of them similary explain that speaking is the most difficult skill to master because speaking happens in real time and as foreign language, environment do not the usage of English

Source : processed primary data Dependent variable (y) : Role play Independent Variable (x) : Low motivation

Data result shows regresion equation $\mathrm{Y}=39.444+0.833 \times$ this can be interpreted as follow :

1. Constante number 39.444 show if motivation $(X)=0$, then students with low motivation will obtain learning result taught by using role play 39.444

2. Regression coefficient 0.833 means that if motivation goes up one unit then the value of learning result wil increase 0.833 as well

Low motivation impact toward role play can be proceed by hypothesis testing with t-test as follows:

1. Determine $\mathrm{H}_{0}$ which state low motivation students do not obtain significance score by using role play

Determine $\mathrm{H}_{\mathrm{a}}$ which state low motivation students obtain significance learning result by using role play

2. Detemine $t$-table value with alpha (a) $5 \%$ or 0.05 and degree of freedom (df) $n-2=9-2=7$. T-table value obtained 1.895

3. Determine t-count value which can be found on table above as 1.323

4. Testing conclution shows that $\mathrm{t}$-count value less than $t$-table value $(1.323<1.895)$ means that $\mathrm{t}$-count located in rejection area. then $\mathrm{H}_{0}$ is accepted and $\mathrm{Ha}$ is rejected.testing can also be proceed by comparing significance value and alpha $(\alpha)$ value. Significance number 0.227 more than alpha (a) 0.05 shows $\mathrm{H}_{\mathrm{a}}$ significance is rejected. Thus low in daily life which is very important to mastering language.

The first issue that researcher concern is which teaching technique is better in order to achieve better speaking skill achievement. sub chapter 4.1 delivers a massage that simulation technique bring better result than role play by using comparative mean testing. Post-test score of simulation technique way better than role play method $(85.32>67.10)$. This result may strengthen Rianis' research that conducted on 2011 who find out the effectiveness of simulation technique to teach speaking skill compared with audiolingual method. In line with this study result, Riani obtain higher mean (61.7) than audiolingual (58.6)

The final issue is when motivation become a variable which bring significance influence toward the result of speaking achievement by using simulation technique and role play. The finding above on Chapter 4.2 and 4.3 explained that high motivation students tend to obtain better result than low motivation students. This result happend in result of Hawley statement who state that motivation bring a good concistency in their study, do more and faster activities.

\section{Conclusion}

Based on finding above, be able to conclude as follow :

1. Speaking skill learning result by using simulation technique significantly better than role play 
2. High motivation students significantly influence toward speaking skill learning result by using simulation technique

3. Low motivation students significantly influence toward speaking skill learning result by using simulation technique.

4. High motivation students significantly influence toward speaking skill learning result by using role play.

5. Low motivation students do not significantly influence toward speaking skill learning result by using role play

\section{Suggestion}

1. to achieve better learning result on speaking skill, it is necessary to apply and improve the simulation technique

2. Simulation technique also need further research in more variant of school in pupose to increse the capability of this learning technique. Then it can be developed rapidly and can reach for every level of education, especially in English to improve speaking skill.

\section{References}

Brown, H.D. 1994. Teaching by Principles. New Jersey:Prentice Hall.

Ellis, Rod. 1994. Principles of Instructed Language Learning. New Zaeland. University of Auckland.

Fauziati, E. 2010.Teaching Emglish as a Foreign Language.Surakarta: Era PustakaUtama.

Iswara, Abi Andaya. 2008. Improving Students' Speaking Fluency Through the Implementation of Trivia-Based Creativity in University Students. Journal.

Kusnierek, Anna. 2015. Developing Students' Speaking Skill Through Role-Play. Poland. World Scientific News, EISSN 2392-2192.

Ma, Rui. 2015. The Role of Pronunciation in Speaking Test Rating. Published Thesis: Bringham Young University. Provo, United State.

Oorade, T. 2012. Developing Speaking Skills Using Three Communicative Activities (Discussion, Problem-Solving, and RolePlaying). International Journal of Social Science and Humanity, Vol. 2, No. 6, November 2012.

Riani. S. 2011. The Effectiveness of Simulation Method to Teach Speaking Skill Viewed from the Students'Self-Confidence (An
Experimental Research on the Eleventh Grade of SMAN 1 Sambung Macan in the Academic Year of 2010/2011). Thesis. Surakarta

Richards, J.C. 2008. Teaching Listening and Speaking from Theory to Practice. New York: Cambridge University Press.

Saputra, Wahyu N E. 2017. The Relation Between Learning Motivation and Learning Outcome of Junior High School Students in Yogyakarta. 1st Yogyakarta International Conferance on Education Management/Administration and Pedagogy.

Shrouf, F. 2011. Teaching and Improving Speaking Skill. Philadelphia: Philadelphia University.

Solcova, B.P. 2011. Teaching Speaking Skills. Published Thesis. Masaryk UniversityFaculty of Arts.

Susilowati, ike. 2012. The Influence of Vocabulary Mastery on Their Speaking Ability at the Fifth Grade of MI Abdul Malik Padalarang. Journal: STKIP Siliwangi. Bandung.

Utami, Nuzulul Dwi. 2012 An Analysis on Students' Effort to Improve Speaking Skill. Journal: Tanjung Pura University. Pontianak.

Wolf, Roger. 2012, Defining the Concept of Creativity. Published Thesis : University of Twente. Netherland. 